\title{
Flipped Classroom as a tool for Information Literacy in academic university Library, A Case Study in Northeast Normal University
}

\author{
Qicun Sun ${ }^{1}$, Chunlei Wang ${ }^{2}$, Ziyu Ning ${ }^{3}$ \\ 1,2,3 Northeast Normal University Library, Changchun, China \\ *wangcl055@nenu.edu.cn
}

Keywords: Flipped Classroom, Information Literacy Education, University Library

\begin{abstract}
Flipped classroom is a new teaching mode accompanied by information-based teaching. As is known the flipped classroom is originally applied to the practice course of basic education, the teacher can organize the teaching activities conveniently according to the personality characteristics of the students, because the overturned class can maximize the students' learning enthusiasm. Through the case analysis of the introduction of the flipped class in the information literacy class of the Northeast Normal University library, the author proves that the overturned classroom is especially suitable for the information literacy education of the university library, and has greatly improved the educational effect of information literacy.
\end{abstract}

\section{Introduction}

The Flipped Classroom was first proposed by J.W. Baker at the 11th International Conference on University Teaching in 2000. The flipped classroom in the information environment, teachers provide teaching video as the main form of learning resources, students complete the teaching video and other learning resources to watch and study before class. Teachers and students in the classroom together complete the homework, collaborative inquiry and interaction and other activities in the new kind of teaching model. In this teaching model, the classroom becomes the place where teachers and students interact together so has been proved achieve better educational results.

The flipped classroom teaching model was first applied to basic education, Rocky Mountain "Woodland Park" High School in Colorado, USA. In the spring of 2007, two chemistry teachers of the school, Jonathan Berman and Aaron Sams, were thinking about how to make up a class for students who were unable to attend classes because they were unable to attend the class, using a video recording software to record a PowerPoint presentation and a teacher's lecture audio, and put a good video on the website. For students who are absent from class. Students who have never been absent also use online materials, mainly for reviewing and strengthening classroom teaching content.

Since 2011, the study of flipped classroom has become popular, and has begun to enter the classroom of higher education. The subjects that apply to it tend to be science-based operational courses. Recently the study of flipped classroom has applied to the information literacy education.

\section{The Reasons of Flipping Classroom Applied to Information Literacy Education in University Libraries}

\subsection{Characteristics of Information Literacy Education}

Information literacy, as a necessary skill quality of students, is essentially different from traditional academic knowledge learning. Therefore, there is no correlation between the two. A student who excels in academic theory may not be equally good at information literacy. On the contrary, a student with excellent information literacy may have a mediocre academic record in a subject. This is because information literacy embodies a person's information literacy, use of information, management information and other information literacy, but does not need to learn the knowledge of high memory, high image thinking ability, logical thinking ability and a high level of mental concentration. For example, information literacy is reflected in "knowing where to find information, 
not the content of the memory itself", "knowing how to identify the information you need in the mass of information, without looking at all the information" and so on. These are the characteristics that traditional knowledge learning does not have.

\subsection{Advantages and Disadvantages of Information Literacy Education in University Libraries}

Library especially the university library is the center of cultural inheritance and information transmission. As an important place for the inheritance of school culture and the procurement and management organization of electronic resources, it has various objective conditions to carry out information literacy education, and is the main organization to train students' literacy.

There are two main modes of information literacy education in university libraries, one is compulsory or elective courses for different grades which must be completed according to the teaching task of the school. Second, according to the characteristics of readers served by university libraries, personalized information literacy training lectures are designed according to different needs.

For the former model, schools have various requirements for teaching indicators, and have strict teaching process management for teachers and students, including curriculum design, teachers' quality, examination results, and file management. But this traditional classroom teaching is rigidly adhering to the type of classroom teaching, and the scale of the class is very large. It is difficult to do specific teaching design for students in different disciplines. It is difficult to examine the real information literacy of the students in essence.

For the second models, because they are set up separately according to the specific needs of the students, they have certain individualization, and they can enter into detailed analysis and explanation for a particular topic of information literacy. Students can master specific information knowledge and tools faster, but this kind of loose lecture style teaching mode is the same. It is difficult to examine students' achievements and the degree of mastery of different students.

\subsection{The significance of flipped classroom access to information literacy education in University Libraries}

Flipped the classroom is a huge subversion of the traditional teaching and learning classroom practice. The specific expression is that the teaching model has changed from a teacher-centered to a student-centered. The role of the teacher is more to guide and organize the classroom order, and the role of the student is transformed from the original passive duckling to active thinking, actively asking questions, thinking about problems and solving problems. In the flipping classroom, students have more time and space for discussion and interaction with each other, which is more conducive to the digestion and understanding of knowledge, and the interactive discussion method, is easier to establish a harmonious student relationship and a harmonious classroom atmosphere.

For colleges and universities, the library is originally a people-oriented service department with user needs as the first driving force. The concept of flipped classroom is a combination of the teaching philosophy of the university and the development concept of the library, especially suitable for library information literacy education. Information literacy education just needs the initiative, enthusiasm and attitude of the students.

\section{Practice of Introducing Flip Classroom in Information Literacy Education of Northeast Normal University Library}

Since 2016, the Northeast Normal University Library has carried out practical teaching of flipping classrooms in information literacy education. The entire teaching design process is divided into course registration, classroom instruction, after-school review and preparation, performance assessment and certificate of completion. 


\subsection{Course registration}

Since this course is not a course prescribed by the school teaching system, but a course designed by the library for the purpose of information literacy education, the pre-course registration and publicity are carried out on the home page of the library, WeChat public signs, publicity posters and other media. For groups, postgraduates are professional, and the subject is information retrieval and utilization. The number of classroom control is around 20. The course lasted for one semester, with 2 classes per week and 40 classes. Located in a small discussion room in the library, the classroom is equipped with projectors, computers, screen cloth, circular conference tables and microphones.

\subsection{Classroom instruction}

In the general flipping class, the instructor uses a certain audio and video tool to record the teaching content in advance. Students need to preview and learn outside the classroom, and then complete the discussion and further study in the classroom. The information literacy flipping classroom of the Northeast Normal University Library did not use the video teaching recorded by the teachers themselves. Instead, the lecturer selects high-quality teaching courseware for information literacy on the Internet, and completes the play in the classroom and the self-study of the students. The reason for adopting this form is that it does not leave students with the burden of academic work under the class. The purpose is to enable students to complete the entire information literacy system as long as they insist on class, and only need to spend a small amount of spare time. In addition, the resources of a library's teachers are limited. Information literacy is a course that requires a wide range of knowledge. The extensive collection of other high-quality courseware from other universities is conducive to broaden the horizons of students, so that students can absorb more under the guidance of the teachers' teaching ideas. Excellent teaching results of many other universities.

\subsection{After-school review and preparation}

The library provides students with computer equipment that can be used in practice, allowing students to focus on or concentrate on the content of the course according to their own situation and research topics. Extensive use of social platforms such as qq group, WeChat group, etc. to publish class ware in a timely manner so that students can learn new things, promote online communication between teachers and students, strengthen communication opportunities between students and promote learning.

\subsection{Performance assessment}

The performance evaluation of the designed course starts from two aspects, one is the attendance rate, and the other is the test score in the classroom. The whole course is designed into 10 themes, each of which has a progressive relationship with each other, but is relatively independent. After completing the course for each topic, there will be 0.5 hours of class time in the class, asking the students to complete the test according to the teacher's requirements, and accumulating the results of each test to get the final grade of the student. The final grade is included in the certificate of completion and the final certificate is issued to prove that the student has completed the course.

\subsection{Practical effect}

The flipped classroom for the information literacy of the Northeast Normal University Library has been opened for two years and has been welcomed by students. Judging from the number of applicants, due to the requirements of venues and teaching effects, the scale cannot be expanded, but the number of applicants is still full. At present, other teaching methods are being tried to meet the needs of students. From the perspective of teaching results, more than $90 \%$ of the students can complete the classroom tasks and complete the assessment as required, and receive the certificate of completion. 


\section{Summary}

In conclusion, the flipped classroom is one of the most effective classroom teaching forms. The practice and exploration of the information literacy of the Northeast Normal University library show that the flipped class is an important classroom mode suitable for the university library to carry out information literacy education. The flipped classroom is especially suitable for information literacy education: the small scale of the class, the students' individualized requirements, and the classroom discussion. Of course, there are many places worth exploring and continuing to study in the information literacy education, which will produce more resonance and research focus in the two fields of library service industry and education and teaching.

\section{References}

[1] J. Zhang, Y. Wang, X.Y. Yang,Practical Research on Flipping Classroom in Information Literacy Education, Library and Information Service, vol. 58,(11),pp.68-72, 2014.

[2] H. Wang, W. Zhao, L.Y. Sun, H.X. Liu, Design of Flipping Classroom Teaching Model—Based on Analysis of Typical Cases at Home and Abroad, Modern Educational Technology, vol.23(08), pp.5-10, 2013.

[3] E. C. Madeline, The Flipped Classroom as a Tool for Engaging Discipline Faculty in Collaboration: A Case Study in Library-Business Collaboration, New Review of Academic Librarianship, vol. 22, pp. 5-23, 2016.

[4] R. Eduaro, Using the Flipped Classroom Model in Your Library Instruction Course, The Reference Librarian, vol. 56, pp.34-41, 2015.

[5] M. Leslie Madden, Ida T. Martinez, The Flipped Library Classroom at Georgia State University: A Case Study, Martinez Georgia Library Quarterly, vol. 52,pp.13-20, 2015.

[6] B. Peter, C.Michele, R.Gregory, Preparing students for Flipped or Team-Based Learning methods, Education Training, vol. 57, pp.639-657, 2015.

[7] M. Fernando, Otero-Saborido, J. Antonio, Sánchez-Oliver, Moisés Grimaldi-Puyana, José Álvarez-García, Flipped learning and formative evaluation in higher education, Education Training, vol. 60, pp.421-430, 2018.

[8] Q. Long, An empirical study on the application of flipped classroom in Information Literacy Education, Journal of Academic Libraries, vol. 32(06), pp.97-102,2014. 